Marcin Leleński

\title{
Glosa do wyroku Trybunału Sprawiedliwości Unii Europejskiej $z$ dnia 28 września 2006 r. w sprawie C 467/04 postępowanie karne przeciwko Giuseppe Francesco Gasparini i innym*
}

Teza orzeczenia

1) Zasada ne bis in idem, zawarta w art. 54 Konwencji wykonawczej do układu z Schengen z dnia 14 czerwca 1985 r. między rządami państw unii gospodarczej Beneluksu, Republiki Federalnej Niemiec oraz Republiki Francuskiej w sprawie stopniowego znoszenia kontroli na wspólnych granicach, podpisanej w dniu 19 czerwca 1990 r. w Schengen, stosuje się do orzeczenia organu sądowego umawiającego się państwa, wydanego $w$ następstwie przeprowadzonego postępowania karnego, w wyniku którego postępowanie karne wobec oskarżonego zostało prawomocnie umorzone $z$ powodu przedawnienia przestępstwa objętego ściganiem.

2) Zasada ta nie znajduje zastosowania do innych osób niż te, których proces zakończył się wydaniem prawomocnego wyroku na terytorium jednej z umawiających się stron.

* Glosa wyróżniona w konkursie organizowanym przez Katedrę Prawa Europejskiego dla studentów WPiA UMK na glosę do orzeczenia Trybunału Sprawiedliwości Unii Europejskiej. 
I. W myśl art. 54 Konwencji wykonawczej do układu z Schengen z 19.06.1990 r. ${ }^{1}$ „Osoba, której proces zakończył się wydaniem prawomocnego wyroku na obszarze jednej Umawiającej się Strony, nie może być ścigana na obszarze innej Umawiającej się Strony za ten sam czyn pod warunkiem, że została nałożona i wykonana kara lub jest ona w trakcie wykonywania lub nie może być już wykonana na mocy przepisów prawnych skazywającej Umawiającej się Strony”. Ponadpaństwowy w ramach Unii Europejskiej wyraz zasady ne bis in idem, znajdujący odzwierciedlenie na gruncie tej konwencji, budzi wiele wątpliwości interpretacyjnych, które były rozstrzygane przez Europejski Trybunał Sprawiedliwości w Luksemburgu w trybie prejudycjalnym.

II. Glosowany wyrok w sprawie C-467/04 został wydany w odpowiedzi na pytanie prejudycjalne sądu Audiencia Provincial de Malaga (Hiszpania). W pierwszym rzędzie wniosek ten dotyczył rozstrzygnięcia wątpliwości, co do stosowania i zakresu zakazu wynikającego $z$ art. 54 Konwencji wykonawczej do układu z Schengen $z 14$ czerwca $1985 \mathrm{r}$.

Wniosek ten został złożony w związku z postępowaniem karnym wszczętym przeciwko Giuseppe Francesco Gasparini i innymi osobom podejrzanym o wprowadzenie do obrotu w Hiszpanii oliwy z oliwek pochodzącej z przemytu. Według ustaleń sądu krajowego, w bliżej nieokreślonym dniu w 1993 r. akcjonariusze i kierownictwo spółki Minerva postanowili wprowadzić przez port Setubal (Portugalia) oliwę $z$ oliwek lampante (tj. rafinowana) pochodzącą z Tunezji i Turcji, która nie została zgłoszona organom celnym. Towar ten został później przetransportowany do Malagi (Hiszpania). Oskarżeni za pomocą fałszywych faktur wykazywali, że oliwa $z$ oliwek pochodzi ze Szwajcarii. Sądy portugalskie orzekający w obu instancjach umarzały postępowanie ze względu na upływ terminu przedawnienia.

${ }^{1}$ Dz.U.WE. z 2000 r., L 239, s.19; polskie wydanie specj. Dz.U.UE. rozdz. 19, t. 2, s. 9. Ilekroć w dalszej części opracowania mowa jest o konwencji bez bliższego jej określania, chodzi o Konwencję wykonawczą z Schengen z 19.06.1990 r., dotyczącą stopniowego znoszenia kontroli na wspólnych granicach. 
W związku z zaistniałą sytuacją, gdy sądy portugalskie orzekające w obu instancjach umorzyły i nie rozpatrzyły merytorycznie sprawy, wobec zaistnienia negatywnej przesłanki procesowej wyłączającej dopuszczalność orzekania co do istoty, sąd w Maladze podjął wątpliwość co do zasadności zastosowania zakazu ne bis in idem, płynącego $\mathrm{z}$ art. 54 KWUS. Zdaniem podejrzanych czyny ich zostały osądzone $\mathrm{w}$ Portugalii. Korzystają więc $\mathrm{z}$ powagi rzeczy osądzonej, a przez to nie mogą być osądzone w Hiszpanii. Audiencia Provincial de Malaga zawiesił więc prowadzone postępowanie i skierował pytanie do Trybunału $z$ wnioskiem o rozstrzygnięcie $\mathrm{w}$ trybie prejudycalnym m.in. następujących kwestii: Czy ocena sądu jednego z państw członkowskich, że karalność przestępstwa uległa przedawnieniu, jest wiążąca dla sądów pozostałych państw członkowskich? Czy umorzenie postępowania wobec oskarżonego z powodu przedawnienia rodzi korzystne skutki względem oskarżonych w innym państwie członkowskim, gdy czyny są tożsame? To jest, czy fakt tego umorzenia wpływa na sytuację innych oskarżonych nieobjętych tym rozstrzygnięciem, gdy czyny te stanowią idem?

III. Trybunał słusznie stwierdził, że nie ma podstaw do nieuruchamiania zakazu płynącego $z$ art. 54 KWUS w sytuacji wydania przez organ sądowy orzeczenia umarzającego postępowania ze względu na upływ terminu przedawnienia. Motywując to, Trybunał odniósł się w pierwszym rzędzie do wykładni literalnej artykułu, która prowadzi do wniosku, że zdanie nadrzędne wchodzące w skład jedynego zdania tworzącego art. 54 nie zawiera żadnego odniesienia do treści wyroku, który stał się prawomocny. Nie jest tak, że stosuje się ono wyłącznie do wyroków skazujących. Ponadto, odwołując się do wykładni teleologicznej, Trybunał wyraził pogląd, że celem tego przepisu jest uniknięcie sytuacji, w której osoby korzystające ze swobody przemieszczania się, mogły narazić się na ściganie za te same czyny na terenie kilku państw członkowskich. Należy więc uważać, że jest to osoba, której proces zakończył się wydaniem prawomocnego wyroku w rozumieniu tego przepisu. Bardzo trafnie przyjęto, że celem stosowania przepisu normującego zakaz ne bis in idem nie jest bynajmniej harmonizacja ustawodawstw, w zakre- 
sie m.in. równych terminów przedawnienia czy też wysokości kar, lecz stworzenie i umocnienie w ramach międzynarodowego obrotu karnego zasady wzajemnego zaufania. $Z$ niej wypływa szereg ważkich zasad o charakterze międzynarodowym, jak na przykład zasada wzajemnego uznawania, o których będzie mowa w dalszej części wywodu. Zasada ne bis in idem nie znajduje zastosowania do innych osób niż te, których proces zakończył się wydaniem prawomocnego wyroku na terytorium jednej $z$ umawiających się stron. Wykładnia taka, oparta na brzmieniu art. 54, znajduje potwierdzenie w celu postanowień tytułu VI Traktatu o Unii Europejskiej, sformułowanym w art. 2 akapit pierwszy tiret czwarte (obecnie art. 3 ust. 1 Traktatu o Unii Europejskiej²).

IV. Przed wydaniem glosowanego wyroku Trybunału z 28 września 2006 r. dominował pogląd, że prawomocne umorzenie postępowania bez rozstrzygnięcia merytorycznego nie powoduje ochrony wynikającej $\mathrm{z}$ zasady ne bis in idem $\mathrm{w}$ płaszczyźnie ponadpaństwowej ${ }^{3}$. Przesłanka formalna, na której podstawie orzeczono w sentencji glosowanego orzeczenia, nie uruchamiała zakazu wynikającego $z$ art. 54 KWUS, gdyż nie prowadziła do oceny merytorycznej sprawy i nie rozstrzygała jej co do istoty.

O ile należy przyjąć za pożądane uznanie przedawnienia za przesłankę, która daje sprawie przymiot „prawomocnego osądzenia”, rozumianego według przepisu konwencji, o tyle nie może to prowadzić do wniosku, że wszystkie przesłanki o charakterze formalnym działają tak samo. Przyjęcie materialnego stanowiska opartego na stosowaniu zakazu jedynie co do zaistnienia przesłanek materialnych dopuszczalności postępowania karnego ${ }^{4}$ nie dawałoby w pełni zadość zagwarantowanego „spokoju prawnego”, łączonego ze swobodą przemieszczania się bez obaw przed kolejnymi postępowa-

${ }^{2}$ Wersje skonsolidowane Traktatu o Unii Europejskiej i Traktatu o funkcjonowaniu Unii Europejskiej; Dz.U.UE. C 83 z 30.3.2010 r.

3 A. Sakowicz, Zasada ne bis in idem $w$ prawie karnym, Białystok 2011 , s. 389 .

4 Tak: Opinia rzecznika generalnego E. Sharpston $z$ dnia 15 czerwca 2006 r. w sprawie Gasparini i innych (C-467/04), ECR (2006), pkt. 92-104. 
niami karnymi w tej samej sprawie, grożącymi w innych państwach członkowskich ${ }^{5}$.

W doktrynie procesu karnego uznaje się przedawnienie za przesłankę o charakterze trwałym i bezwzględnym, co znaczy, że jej zaistnienie zawsze będzie prowadzić do zakończenia postępowania bez rozstrzygnięcia sprawy co do istoty i bez względu na stadium postępowania, w którym się znajduje. Niektórzy przypisują przesłance przedawnienia charakter mieszany (materialno-formalny) ${ }^{6}$. Zaistnienie przesłanki o charakterze względnym, jak na przykład brak skargi uprawnionego oskarżyciela (art. $17 \S 1$ pkt 9 polskiego KPK), nie uruchamia zakazu ne bis idem, ponieważ trudno jest uznać w tym przypadku nadrzędność zasady swobodnego przemieszczania się nad potrzebą zapewnienia „przestrzeni wolności, bezpieczeństwa i sprawiedliwości”, którą wyraża art. 3 TUE i art. 67 TFUE.

v. Zasadniczą kwestią przy stosowaniu zasady ne bis in idem w rozumieniu art. 54 konwencji wykonawczej z Schengen jest interpretacja terminu „prawomocne osądzenie”, który został użyty w polskiej wersji tej umowy. Nie jest jasne, czy należy go odnosić wyłącznie do wyroków skazujących i uniewinniających, czy objąć nim także wyroki umarzające i warunkowo umarzające postępowanie oraz niepochodzące od sądu prawomocne orzeczenia kończące postępowanie przygotowawcze. Językowa interpretacja tego wyrażenia w polskiej wersji wskazuje na odniesienie wyłącznie do orzeczeń sądowych. Podobnie zwrot rechtskräftige Aburteilung użyty w niemieckiej wersji konwencji, wyrażający wyłącznie orzeczenia sądowe, wydane na rozprawie głównej czy też a person whose trial has been finally disposed of. Z tej perspektywy dziwi pogląd ETS co do braku przesłanek uzasadniających twierdzenie, że termin „prawomocne osądzenie” odnosi się wyłącznie do orzeczeń sądo-

5 Pkt 27 wyroku ETS z 28 września 2006 r. w sprawie Gasparini i innych (C-467/04).

6 P. Grzegorczyk, J. Tylman, Polskie postępowanie karne, Warszawa 2009, s. 179-180. 
wych $^{7}$. Trybunał wielokrotnie wydawał wyroki, które interpretowały ten termin. Jednym $z$ przykładów jest rozstrzygnięcie Trybunału w połączonych sprawach Gözütok (C-187/01) i Brügge (C-385/01), które uznało, że postanowienie prokuratorskie kończące postępowanie karne i związane $z$ nałożeniem obowiazku zapłaty określonych sum pieniężnych, powoduje stan rzeczy osądzonej w rozumieniu art. 54 konwencji. Dla oceny możliwości zastosowania zasady ne bis idem nie ma również znaczenia okoliczność, czy już w czasie wydania pierwszego orzeczenia państwo było związane konwencją wykonawczą z Schengen ${ }^{8}$.

Reasumując, przyjecie wąskiego rozumienia terminu „prawomocne osądzenie" jako odnoszącego się jedynie do wyroków skazujących i uniewinniających prowadziłoby do zagrożenia prawa do swobodnego przemieszczania się na terenie całej UE. Ponadto $\mathrm{w}$ wielu przypadkach stwarzałoby również zagrożenie dla zasad pewności prawnej.

VI. Trybunał w wyroku dużo uwagi poświęcił zasadzie wzajemnego zaufania do systemów sądownictwa karnego, a także faktowi, że każde ze wspomnianych państw akceptuje stosowanie prawa karnego obowiązującego $\mathrm{w}$ innych umawiających się państwach, nawet gdy zastosowanie własnego prawa krajowego prowadziłoby do innego rozwiązania. Zasada ta jest więc wypadkową stosowania zasady ne bis in idem. Ze wzajemnym zaufaniem bezsprzecznie łączy się zasada wzajemnego uznawania, która jest jedną $z$ zasad prawa unijnego i ma ogromne znaczenie w budowaniu wspólnego rynku, stanowi ponadto najbardziej efektywny sposób zapewnienia wolnego przepływu towarów9 .

Zasada wzajemnego zaufania, jak to wynika $z$ Programu haskiego ${ }^{10}$, zdaje się warunkiem sine qua non utworzenia europej-

7 B. Nita, Zasada ne bis in idem $w$ międzynarodowym obrocie karnym, Państwo i Prawo 2005, nr 3, s. 25.

8 Wyrok ETS z 9.03.2006 r. w sprawie C-436/04 Postępowanie karne przeciwko Leopold Henri Van Esbroeck, ECR(2006), pkt. 18-24.

9 A. Sakowicz, op.cit., s. 175.

10 Program haski: Wzmocnienie wolności, bezpieczeństwa i sprawiedliwości w Unii Europejskiej, (2005/C53/01) Dz.U. C 53, 3.3.2005. 
skiego obszaru sądowego. Traktat lizboński podniósł w art. 67 TFUE rangę zasady wzajemnego uznawania orzeczeń. Szczególnie ust. 4 traktatu stanowi wprost, że „Unia ułatwia dostęp do wymiaru sprawiedliwości, w szczególności przez zasadę wzajemnego uznawania orzeczeń sądowych i pozasądowych w sprawach cywilnych”. Jako podwalinę wzajemności należy także uznać zasadę lojalności wyrażoną w art. 4 ust. 3 TUE, a której istotą jest „konieczność współpracy i współdziałania w urzeczywistnianiu celów Unii Europejskiej oraz podejmowania przez państwa członkowskie wszelkich działań prowadzących do ich osiągnięcia" ${ }^{11}$.

Trudno wyobrazić sobie skuteczną współpracę w sparawach karnych bez zrzeczenia się przez państwa w znacznym zakresie ius puniendi na rzecz innych podmiotów prawa międzynarodowego, w szczególności innych państw. Warto zauważyć, że zasada ne bis in idem w sferze prawodawstwa unijnego doznawała do $1999 \mathrm{r}$. wielu braków. Ważną cezurą było włączenie na mocy art. 1 Protokołu Dodatkowego do Traktatu Amsterdamskiego z 2 października 1997 r. ${ }^{12}$ acquis Schengen do prawa Unii Europejskiej. Zgodnie $\mathrm{z}$ art. 2 ust. 1 Protokołu od dnia wejścia w życie Traktatu Amsterdamskiego (tj. od 1 maja 1999 r.) postanowienia składające się na acquis Schengen będą stosowane automatycznie pomiędzy 13 państwami UE (czasowo wyłączono Wielką Brytanię i Irlandię). Obecnie wszystkie państwa członkowskie UE (w tym Polska) są związane regulacjami KWUS. Istotna $\mathrm{z}$ punktu widzenia systemowego ujęcia zakazu ne bis idem jest Konwencja europejska o międzynarodowej ważności wyroków karnych z 28.05.1970 r., która odnosi tę zasadę do wyroków karnych w jak najszerszym znaczeniu, explicite wskazując w art. 53 ust. 1 pkt b. sytuację, gdy orzeczona kara nie może być wykonana $\mathrm{z}$ powodu przedawnienia ${ }^{13}$.

W uzasadnieniu wyroku Trybunał powołał się na art. 3 pkt 2 i art. 4 pkt 4 Decyzji Ramowej Rady UE nr 2002/584/JAI z 13 czerwca 2002 r. w sprawie europejskiego nakazu aresztowania

11 Podstawy prawa Unii Europejskiej z uwzględnieniem Traktatu z Lizbony, red. J. Galster, Torun 2010, s. 265.

12 Dz.U.WE. C 340, 2.10.1997 r., s. 1.

13 Obecnie łączy 14 państw (Polska nie jest stroną) i z powodu wąskiego grona sygnatariuszy nie spowodowała zamierzonych skutków. 
i procedury wydawania osób między państwami członkowskimi ${ }^{14}$, które stanowią obligatoryjne i fakultatywne przesłanki odmowy wykonania europejskiego nakazu aresztowania. Artykuł 3 pkt 2 formułuje obligatoryjną przesłankę zastosowania w sytuacji, gdy zapadło w związku $z$ popełnieniem tych samych czynów prawomocne orzeczenie $\mathrm{w}$ państwie członkowskim $\mathrm{z}$ zastrzeżeniem, że jeśli została orzeczona kara, to została ona wykonana lub jest wykonywana, lub też nie może być dłużej wykonywana w świetle prawa państwa członkowskiego, w którym nastąpiło skazanie.

$\mathrm{W}$ art. 4 pkt 4 jako jedną $\mathrm{z}$ fakultatywnych przesłanek jest sytuacja, gdy zgodnie $z$ prawodawstwem wykonującego nakaz państwa członkowskiego ściganie karne lub ukaranie osoby, której dotyczy wniosek, jest ustawowo zakazane i gdy czyny podlegają jurysdykcji tego państwa członkowskiego na podstawie jego prawa karnego. Trudno uznać za wystarczające powołanie się przez Trybunał jedynie na fakultatywną przesłankę $z$ art. 4 pkt 4 przy argumentacji swojego rozstrzygnięcia, skoro w myśl tej decyzji można przy zaistnieniu tej przesłanki nie odstąpić od wykonania ENA.

VII. Glosowany wyrok bez wątpienia stanowi krok milowy w zakresie rozwoju zasady ne bis in idem w europejskim obszarze sądowym. Słuszne w mojej ocenie rozstrzygnięcie Trybunału prowadzi do rozszerzenia gwarancyjnego charakteru tej zasady i umocnieniu zakresu współpracy. Można sobie zatem zadać pytanie, gdzie leżą przeszkody ograniczające realizację instrumentów opartych na zasadzie wzajemnego uznawania w obszarze europejskiej współpracy w sprawach karnych. Za taki hamulec można uznać w ramach paneuropejskiego obszaru współpracy tradycyjne rozumienie suwerenności państwowej, $z$ „nieustannym hołubieniem tezy, iż władza suwerenna ma charakter terytorialny w myśl zasady par in parem non habet imperium"15. Skuteczne mechanizmy przeciwdziałania przestępczości są warunkiem zapewnienia swobody przemieszczania się osób, bezpieczeństwa oraz porządku prawnego. Do stworzenia takich mechanizmów niezbędne jest zreformowanie spojrzenia

14 Dz.U.WE. z 2002 r. L 190.

15 A. Sakowicz, op.cit., s. 248. 
na suwerenność państwową oraz wzmacnianie wzajemnego zaufania do ustawodawstw karnych państw Unii Europejskiej. Wąska interpretacja art. 54 KWUS byłaby w sprzeczności $z$ europejską tendencją do przyspieszania i upraszczania procedur przez stosowanie alternatyw wobec orzekania na rozprawie głównej. Upływ terminu przedawnienia jako przesłanka formalna, ale o charakterze nieusuwalnym, bez wątpienia uruchamia zakaz płynący $z$ konwencji. W przypadku przesłanek o charakterze usuwalnym art. 54 nie może mieć zastosowania, gdyż stwarzałoby to zagrożenie dla fundamentalnych zasad bezpieczeństwa i sprawiedliwości.

\section{SUMMARY}

\section{Commentary on European Court of Justice judgement of 28 September 2006 in case C-467/04 Giuseppe Francesco Gasparini et al}

1. The ne bis in idem principle, enshrined in Article 54 of the Convention implementing the Schengen Agreement of 14 June 1985 between the Governments of the States of the Benelux Economic Union, the Federal Republic of Germany and the French Republic on the gradual abolition of checks at their common borders, signed in Schengen on 19 June 1990, applies in respect of a decision of a court of a Contracting State, made after criminal proceedings have been brought, by which the accused is acquitted finally because prosecution of the offence is time-barred.

2. That principle does not apply to persons other than those whose trial has been finally disposed of in a Contracting State.

Keywords: Convention implementing the Schengen Agreement, Article $54, \mathrm{Ne}$ bis in idem principle 